\title{
Blunt Minor Thoracic Trauma: A Prospective Analysis of 186 Patients in the Emergency Department
}

\author{
Künt Minör Toraks Travması: Acil Servise Bașvuran 186 Hastanın Prospektif Analizi
}

\author{
Faruk Güngör, Kamil Can Akyol, Taylan Kılıç, Mustafa Keșaplı, Asım Arı, Ali Vefa Sayraç \\ Antalya Eğitim ve Araştırma Hastanesi, Acil Tip Kliniği, Antalya, Türkiye
}

\begin{abstract}
Aim: There is limited information regarding patients with blunt minor thoracic traumas (MTT) in terms of diagnosis, treatment, emergency department (ED) management and follow-up after discharge. The aim of this research, was to investigate demographics, physical examination findings and their predictive value for concomitant thoracic injuries, and outcomes of patients.
\end{abstract}

Material and Method: The mechanism of injury, physical examination findings, radiographic findings, pain levels, discharge and hospitalization diagnoses were recorded prospectively.

Results: $A$ total of 186 patients with a mean age of $48 \pm 17$ (1891) years were included in the study. 131 of the (70.4\%) patients were males. 171 of the patients (91.9\%) were discharged, while 15 (8.1\%) patients were hospitalized. The most common diagnosis and physical finding were soft tissue trauma, and tenderness at injury site $(78.8 \%, 15.1 \%, 69.6 \%)$, respectively. The specificity of physical findings in predicting concomitant thoracic injuries were found to be $100 \%$, although their sensitivities were too low. The initial and 7th day pain levels of the patients with recurrent admissions were significantly higher $(p=0.019, p=0.025)$.

Conclusion: Most patients are discharged from ED without significant morbidity and mortality. Patients exhibiting the positive physical findings require detailed investigation for concomitant thoracic injuries. As severe and long-lasting pains are determinants of hospital re-admissions, it would be appropriate to provide adequate analgesia and detailed information about the pain.

Key words: minor blunt thoracic trauma; physical examination; pain and analgesia

\section{ÖZET}

Amaç: Künt minör toraks travmalı (MTT) hastalarda tanı, tedavi, acil servis (AS) yönetimi ve taburculuk sonrası takip bakımından bilgiler kısıtıdır. Hastaların demografik verilerini, fizik muayene bulgularını ve bu bulguların eșlik eden torasik yaralanmaları ön görmedeki değerliklerini, hastaların sonlanımlarını araștırması amaçlandı.

Faruk Günör, Varlık Mah. Kazımkarabekir Cad. 07100 Antalya - Türkiye, Tel.05056892041Email.drfarukgungor@gmail.com

Geliş Taribi: 21.05.2016 • Kabul Taribi: 31.05.2017
Materyal ve Metot: Yaralanma mekanizması, fizik muayene bulguları, görüntüleme bulguları, ağrı düzeyleri, taburculuk ve hastaneye yatıș tanıları prospektif olarak çalıșma formuna kaydedildi.

Bulgular: Çalıșmaya, alınan 186 hastanın yaș ortalaması 48 \pm 17 (18-91) 131'i $(\% 70,4)$ erkekti. Hastaların 171'i $(\% 91,9)$ acil servisten taburcu edilirken, $15^{\prime} i(\% 8,1)$ hastaneye yatırıldı. En sık tanı, yumușak doku travması $(\% 78,8)$ ve en sık muayene bulgusu yaralanma yerinde duyarlııktı $(\% 69,6)$. Duyarlııkları çok düșük olsa da fizik muayene bulguları eșlik eden torasik yaralanmaları saptamadaki özgüllükleri \%100 bulundu. Tekrarlayan bașvurusu olan hastaların bașlangıç ve 7. gündeki ağrı düzeyleri istatistiki olarak daha yüksek saptand $ı(p=0,019, p=0,025)$.

Sonuç: MTT'lı çoğu hasta, önemli bir morbidite ve mortalite olmadan AS'den taburcu edilmektedir. Pozitif fizik muayene bulguları bulunan hastalar, eșlik eden torasik yaralanmalar açısından detaylı araștırılmalıdır. Ciddi ve uzun süren ağrı tekrar bașvuruların belirleyicileri olduğundan yeterli analjezik tedavi sağlanarak ağrı konusunda hastalar detaylı bilgilendirmelidir.

Anahtar kelimeler: minör künt toraks travması; fizik muayene; ağrı ve analjezi

\section{Introduction}

Trauma is a major cause of mortality and morbidity in all age groups. The most frequent causes of trauma are motor vehicle accidents, falls, firearm accidents, sharp and penetrating injuries, and burns. Thoracic traumas are the third most common trauma following headneck and extremity traumas ${ }^{1}$. And they are responsible for $25 \%$ of deaths occurring after blunt trauma ${ }^{2,3}$. However, they do not always lead to fatal injuries. Minor thoracic trauma (MTT) and suspected rib fractures are also frequent reasons for emergency department (ED) admissions ${ }^{4}$; many of these patients are treated as outpatients ${ }^{5}$. Nonetheless, although rib fractures or chest wall injuries are not life threatening, they may represent a significant cause of repeated hospital admissions and decreased living comfort ${ }^{4-6}$. Indeed, 
$10 \%$ of patients with MTT may develop delayed complications within 14 days after discharge from $\mathrm{ED}^{7}$.

However, studies regarding demographics, ED treatment and management, and follow-up of patients with MTT after discharge are, at present, limited. Therefore, in our study, we aimed to investigate age, gender, physical examination findings, the correlation between pathological physical examination findings and concomitant thoracic injuries (CTIs), ED final diagnosis, hospitalization, discharge and re-admission rates, and the effects of prescribed analgesics on pain and re-admissions of patients with a pre-diagnosis of blunt MTT on first admission.

\section{Material and Method}

Patients who had pain (primarily located in the thoracic cage), abrasion, contusion, or bruising of the thorax due to the blunt thoracic trauma with a Glasgow Coma Scale (GCS) of 15 and stable vital signs at the initial examination other than a suspicion of CTI were considered to have pre-diagnosis of blunt MTT. And blunt MTT patients who were over 18 years of age and had been admitted to the training and research hospital between July, 2013 and April, 2014 within 24 hours after injury were included in the study. Blunt MTT patients who had superficial soft tissue trauma such as abrasion, contusion, edema or bruising on the other parts of the body without requiring any suspicion of orthopedic or surgical intervention according to initial examination findings were, also, included in the study. However, patients who did not agree to participate in the study and as well as multitrauma patients accompanied by thoracic trauma were excluded from the study. Age, gender, mechanism of injury, physical examination findings, and other accompanying injuries (AIs) of the patients were recorded prospectively on the study paper. Rib fractures, hemothorax, pneumothorax and lung contusions are determinants of hospitalization and can increase the morbidity and sometimes mortality of patients. Therefore, these diagnoses were defined as CTIs. And other organ system injuries accompanying to the thoracic trauma defined as AIs. We provided no guidance for diagnostic tests, treatment choices, and management of the patient, leaving those decisions to the treating physicians' discretion compatible with clinical practice conducted in our facility. In our clinical practice, patients were evaluated first with physical examination and then with a chest X-ray (FDX 4343R; US X-RAY, Bolu, Turkey) for thoracic injuries. If there was an injury detected at the lower parts of the thoracic cage, an ultrasound (Esaote, Mylab Class-C, Italy) examination was performed. If there were pathological findings according to the physical examination or chest $\mathrm{X}$-ray, the recommended imaging modality should be a chest computed tomography (CT), (Eclos WS-18A, Hitachi Tokyo, Japan). The prescribed analgesic option on discharge was left to the discretion of the physician who first examined the patient. Radiographic findings, severity of pain on the numeric pain scale, recommended analgesic type, and discharge and hospitalization diagnoses were recorded on to the study paper. Patients enrolled in the study were contacted on the 7 th and 30th days after discharge from ED via phone call, regarding the issues of repeated hospital readmissions, pain levels and satisfaction with the treatment prescribed.

The study data were analyzed in SPSS 22.0 for Windows (IBM, Armonk, NY, USA). Frequent variables were presented as rates and the numeric variable as a mean \pm standard deviation. Physical examination findings predicting lung injury due to final diagnosis were measured by calculating sensitivity, specificity, and positive and negative predictive values. Two-group comparison of categorical variables was performed by chi-square test and two-group comparison of numerical variables with normal distribution was performed by student-t test. The normality analysis was performed by Kolmogorov-Smirnov test. All the hypotheses were constructed as two-tailed and an alpha critical value of 0.05 was accepted as significant.

\section{Results}

462 patients with blunt chest trauma were accepted to the ED within study time. 248 multitrauma patients, 14 patients with unstable vital signs, and 4 patients with a GCS of less than 15 were not met inclusion criteria and excluded from the study. 10 patients who were presented to the ED after 24 hours following injury were excluded, also. 186 patients who met inclusion criteria were included in the study analysis. Of these 186 patients, $131(70.4 \%)$ were male and 55 (29.6\%) were female; the mean age was $48 \pm 17$ years ( $\min : 18$, max: 91) (Table 1). 171 patients (91.9\%) were discharged from ED and 15 (8.1\%) patients were hospitalized. Of those 15 patients, 5 patients had tube thoracotomy due to pneumothorax in 4 patients and hemopneumothorax in another patient. Of those patients with AIs, one patient underwent abdominal surgery, and another 
patient underwent extremity surgery (Table 1$)$. In this way, $7(3.8 \%)$ of all the study patients needed to have invasive surgical interventions. The average hospital stay of the hospitalized patients was found to be $3.8 \pm 2$ days and none of these patients resulted in significant morbidity or any mortality.

Regarding the mechanism of injury, 90 patients (48.2\%) were admitted due to a fall from their own height. Other causes of injury are shown in Table 1.

Table 1. Demographics and study results of the patients

\begin{tabular}{|c|c|c|}
\hline Variables & $\mathrm{n}$ (number) & $\%$ \\
\hline \multicolumn{3}{|l|}{ Causes of the trauma } \\
\hline Fall from the patient's own height & 90 & 48.2 \\
\hline Fall from greater than the patient's own height & 18 & 10 \\
\hline Direct blunt injury & 43 & 23 \\
\hline Bike accident & 6 & 3.2 \\
\hline Motorcycle accident & 4 & 2.2 \\
\hline MVA & 6 & 3.2 \\
\hline Pedestrian and MVA & 4 & 2.2 \\
\hline Other & 15 & 8 \\
\hline Total & 186 & 100 \\
\hline \multicolumn{3}{|l|}{ Physical examination findings } \\
\hline Abrasion/Ecchymosis & 33 & 17.7 \\
\hline Subcutaneous emphysema & 3 & 1.6 \\
\hline Tenderness on palpation & 129 & 69.4 \\
\hline Crepitus over ribs & 11 & 6 \\
\hline Decreased respiratory sounds & 5 & 2.7 \\
\hline Pathological respiratory sounds & 10 & 5.4 \\
\hline \multicolumn{3}{|l|}{ Chest CT Results } \\
\hline Rib fractures & 9 & 15 \\
\hline Contusion & 5 & 8.2 \\
\hline Pneumothorax & 3 & 5 \\
\hline Contusion, hemothorax, pneumothorax & 1 & 1.7 \\
\hline Rib fractures, contusion & 1 & 1.7 \\
\hline Hemo-pneumothorax & 2 & 3.3 \\
\hline Rib fractures, contusion, hemothorax & 1 & 1.7 \\
\hline Rib fractures, contusion, pneumothorax & 1 & 1.7 \\
\hline Rib fractures, hemothorax & 1 & 1.7 \\
\hline Rib fractures, liver injury & 1 & 1.7 \\
\hline Normal & 35 & 58.3 \\
\hline Total & 60 & 100 \\
\hline Detected Thoracic Injuries & 28 & 15.1 \\
\hline Rib fractures* & 10 & 5.4 \\
\hline Pneumothorax ${ }^{\star \star}$ & 6 & 3.2 \\
\hline Hemothorax ${ }^{\star \star \star}$ & 11 & 5.9 \\
\hline Contusion & 145 & 78.8 \\
\hline \multicolumn{3}{|l|}{ Soft tissue injuries } \\
\hline \multicolumn{3}{|l|}{ Accompanying Injuries } \\
\hline Extremity & 21 & 56.8 \\
\hline Head & 10 & 27 \\
\hline Abdomen & 1 & 2.7 \\
\hline Other region & 5 & 13.5 \\
\hline Total & 37 & 100 \\
\hline
\end{tabular}

* Other pathologies are also found in 12 patients with rib fractures

** Pneumothorax is accompanied by hemothorax in 3 patients and contusion in 2 patients.

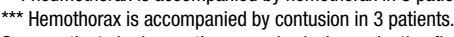

Some patients had more than one physical examination finding and concomitant thoracic injury at the same time. Therefore, total number of patients and percentages may not reach to the total study patients of 186 and $100 \%$, respectively. MVA: Motor vehicle accidents. CT: Computed tomography.
Regarding the site of injury, the most common sites were anterolateral thorax and at the level of 7 th- 8 th ribs, while the most common physical examination finding was tenderness on palpation at the injury site $(\mathrm{n}=129,69.4 \%)$. Of all the examination findings, tenderness at injury site had the lowest specificity (32.41\%; 95\% CI: 24.68 to 40.88$)$ and highest sensitivity (75.61\%; 95\% CI: 59.69 to 97.62$)$ in predicting CTIs. The specificity and positive predictive value of ecchymosis/abrasion for CTIs were found to be significantly higher when compared to tenderness on palpation $(88.89 \%$ to $32.31 \%$ and $51.52 \%$ to $24.03 \%$ ). The specificity and positive predictive values of crepitus over rib, decreased respiratory sounds, subcutaneous emphysema and pathological respiratory sounds were found to be $100 \%$, but their sensitivities were found to be too low. Other physical examination findings are shown in Table 1 . The relationship between physical examination findings and CTIs is shown in Table 2.

During the evaluation process, all patients underwent a chest X-ray for the detection of possible thoracic injuries; in addition, $60(32.3 \%)$ patients had chest CT and $28(15.1 \%)$ patients had ultrasound examinations. 24 of the ultrasound examinations were performed on the patients with injuries at the level of 5 th rib or below; intra-abdominal free fluid was detected in one patient and hemothorax in another patient. Ultrasound results of the other 26 patients were assessed as normal. The chest CT results of 35 (58.3\%) patients were found to be normal, and the most common pathological CT finding was rib fractures $(n=14,23.3 \%)$ (Table 1). The most common diagnosis was soft tissue trauma $(n=145,78.8 \%)$ and the most frequent thoracic injury was rib fractures detected by both chest X-ray and CT $(n=28,15.1 \%)$. Other injuries are shown in Table 1. CTIs were detected in a total of $41(22 \%)$ patients. AIs were detected in 37 (19.9\%) patients. And, the most common AIs were extremity injuries ( $\mathrm{n}: 21,56.8 \%$ ) and minor head trauma $(\mathrm{n}=10,27 \%)$ (Table 1$)$.

Breathing exercises and analgesic tablets were found to have been recommended to all patients discharged from ED. As an analgesic drug, physicians prescribed non-steroidal anti-inflammatory drugs (NSAIDs) and a codeine combination in 87 (46.8\%) patients, NSAIDs in 63 (33.9) patients, and paracetamol in 47 (25.5\%) patients. When patients were questioned about their satisfaction with the analgesic treatment prescribed, no significant difference was found (Table 3 ). 
Table 2. The values of physical examination findings in predicting the concomitant thoracic injuries

\begin{tabular}{lcccc}
\hline & \multicolumn{3}{c}{ Concomitant thoracic injuries } \\
\cline { 2 - 5 } Physical examination findings & Sensitivity (\%) & Specificity (\%) & PPV (\%) & NPV (\%) \\
\hline Ecchymosis/abrasion & 39.02 & 88.89 & 51.52 & 83.66 \\
Tenderness on palpation & 75.61 & 32.41 & 24.03 & 82.46 \\
Crepitus over the ribs & 26.83 & 100 & 100 & 82.86 \\
Subcutaneous emphysema & 7.32 & 100 & 100 & 79.23 \\
Decreased respiratory sounds & 12.2 & 100 & 100 & 80.11 \\
Pathological respiratory sounds & 24.39 & 100 & 100 & 82.4 \\
\hline
\end{tabular}

*Rib fracture, pneumothorax, haemothorax contusion defined as concomitant thoracic injuries. PPV: Positive predictive value, NPV: Negative predictive value.

The average pain level in all patients was $5.68 \pm 1.8$, measured by the numerical pain scale. When questioned by phone call after discharge, the average level of pain was $1 \pm 1.2$ on day 7 , and the pain lasted an average of $9.8 \pm 7.7$ days. When re-admission rates were examined, 50 (26.8\%) patients were found to have been re-admitted to the hospital, although no additional pathology was detected in any of these patients. In terms of the preferred analgesic drugs in patients who were re-admitted, there was no significant difference (Table 4). However, the initial and 7th day average pain levels of those patients with recurrent hospital admissions were found to be statistically and significantly higher than other patients $(\mathrm{p}=0.019, \mathrm{p}=0.025)$ (Table 5).

\section{Discussion}

As in all other system injuries, the most common cause of chest trauma is motor vehicle accidents ${ }^{8,4,9}$. However, in our study, falls from the patients' own height was found to be the most common cause of blunt MTT (n: 151, 81.2\%).

AI rate is known to be $35-40 \%$ in patients with major thoracic trauma ${ }^{10,11}$. However, in our study, AI rate has been identified as $19.9 \%$ and the most common AI was found to be extremity injuries, which is consistent with the literature ${ }^{11}$. Unlike major thoracic trauma patients, AIs in our study patients were found to be simple injuries, not causing any serious increase in morbidity and mortality. These patients were mostly treated as outpatients, and only 7 patients needed to have invasive surgical interventions.

Rib fractures are the most common injury in thoracic trauma $(7-40 \%)^{12}$. They are often neglected in the presence of AIs. But, if appropriate treatment and follow-up are not provided, they can result in significant morbidity and mortality $3,4,13,14$. However, none of the patients in the study with rib fractures resulted in significant morbidity or any mortality.

Although we assessed blunt MTT patients in our study, CTIs accompanying to rib fractures were found in 41 (22\%) of the patients, compatible with the literature ${ }^{11}$. In a prospective study by Plourde et al. ${ }^{15}$ which included 450 patients, single rib fractures between 3-9 ribs were found to be a significant risk factor for delayed hemothorax and pneumothorax. However, no pulmonary complication was observed in the outpatients

Table 3. Satisfaction status of the patients by treatment drug groups

\begin{tabular}{lccc}
\hline Treatment drug groups & Not satisfied & Satisfied & P value \\
\hline Paracetamol & 5 & 34 & 0.677 \\
NSAIDs and codeine & 15 & 80 & 0.429 \\
NSAIDs & 7 & 55 & 0.244 \\
\hline
\end{tabular}

NSAIDs: Non-steroidal antiinflammatory drugs.

Table 4. Comparison of treatment drug groups in re-admitted patients

\begin{tabular}{llll}
\hline & \multicolumn{2}{c}{ Re-admissions } & \\
\cline { 2 - 3 } Treatment drug groups & Yes & No & P value \\
\hline Paracetamol & 26 & 61 & 0.386 \\
NSAIDs and codeine & 13 & 34 & 0.889 \\
NSAIDs & 17 & 46 & 0.982 \\
\hline
\end{tabular}

NSAIDs: Non-steroidal antiinflammatory drugs.

Table 5. Initial and 7th day pain levels of re-admitted and all patients

\begin{tabular}{lccc}
\hline Pain level & All patients & Re-admitted patients & $P$ value \\
\hline Initial pain level & $5.68 \pm 1.8$ & $6.4 \pm 2$ & 0.019 \\
Pain level on day 7 & $1 \pm 1.2$ & $1.34 \pm 1.22$ & 0.025 \\
\hline
\end{tabular}

Pain levels were measured by numeric pain scale. 
without CTIs at the first admission. The reason for this might be the high rate of chest CT imaging (32.2\%) in our practice and high compliance of patients with the treatment recommendations. Although rib fractures are suspected due to the mechanism of injury, physical examination findings, or sometimes severe thoracic pain, the fractures, always, can not be detected easily with conventional radiographs ${ }^{16-18}$. A simple chest $\mathrm{X}$-ray may not be adequate in the diagnosis of rib fractures $^{18}$. In a study evaluating the multislice chest CT findings of patients with blunt thoracic trauma, Palas et al. found that chest CT can be applied quickly, provides very detailed information and often changes the decision of physician made by conventional methods ${ }^{19}$.

In our study, rib fractures were detected by chest $\mathrm{CT}$ in $14(50 \%)$ of 28 patients. When the frequency of CTIs is taken into consideration, the use of additional imaging techniques such as additional radiographs, ultrasound or chest CT may also be required in the patients with rib fractures.

The presence of pathological physical examination findings was found to have high positive predictive value for the prediction of CTIs. Therefore, patients with blunt MTT and pathological physical examination findings should be carefully evaluated for possible CTIs ${ }^{19}$.

Chest wall trauma can cause severe pain. Although there was a selected group of outpatients with minor injuries in our study, it was shown that the average pain level of these patients was high and the pain persisted for long time (an average of 10 days).

There are studies stating that patients with MTT and rib fractures do not receive appropriate and adequate treatment. These studies particularly have focused on the patients without analgesic prescription for painful conditions ${ }^{6}$. However, analgesics were prescribed to all patients in our study at discharge. Currently, the most commonly prescribed analgesics are NSAIDs, opioids and paracetamol, like in our study ${ }^{18}$. The drug choice of physicians varies according to the patients' pain level and detected pathology. The number of rib fractures and the extent of the injury site affect the medication choice at the ED and during discharge ${ }^{18}$. Consequently, this situation may be the cause of prescribing inadequate analgesia for the patients only having soft tissue injuries without any CTIs.

Although higher treatment satisfaction was noted in the study, $26.6 \%$ of patients discharged from ED were re-admitted to the hospital within three days in whom the main complaints were ongoing pain and inadequate analgesia. However, there was no significant difference in terms of analgesic treatments prescribed between re-admitted and other patients. Therefore, each of the analgesic drug groups can be safely prescribed to the outpatients separately or in combination with each other. Pain levels and ongoing pain appeared to be more influential on the re-admissions than the diagnosis of patients. And in some patients, adequate analgesic treatment could not be achieved with the current treatment recommendations ${ }^{18}$. While the pain level of patients who were re-admitted was statistically higher compared to the other patients, the clinical significance of this difference is controversial. As well as prescribing analgesic treatment, giving detailed information about the current painful condition to the patients with blunt MTT can increase the treatment adherence and reduce the re-admission rate.

Although delayed complications in patients with blunt MTT during the period of 7-14 days after discharge are reported in some studies, in our study, no delayed complication was observed in any of the patients within 30 days of discharge $\mathrm{e}^{7,18,20}$. As long as appropriate analgesic treatment and follow-up recommendations are provided, it seems to be appropriate to discharge these patients with either one rib fracture or chest wall soft tissue trauma without CTIs at the first admission.

Hospitalization rate and duration of hospital stay were lower when compared to patients with major thoracic trauma ${ }^{10}$. As our study patients were exposed to lowenergy trauma, only 7 (3.8\%) of all the study patients needed to have invasive surgical interventions. In this way, lower morbidity rate was established without any mortality. However, in the initial evaluation of blunt MTT patients, a detailed query and examination should be performed in order to exclude possible lifethreatening conditions and diagnostic imaging should be performed in all the patients with abnormal physical examination findings and severe pain.

Regarding blunt MTT, most patients were young males, diagnosed with chest wall soft tissue trauma due to a fall from their own height. Although most patients were discharged from ED without significant morbidity or any mortality, patients with pathological physical examination findings should be evaluated carefully for CTIs. As, severe and long-lasting pains are determinants of hospital re-admissions, blunt MTT patients without CTIs can be safely treated as outpatients with adequate analgesia and detailed information about the pain. 


\section{Limitations}

A significant limitation of the study was that we provided no guidance for diagnostic tests, treatment choices, and management of the patient, leaving those decisions to the treating physicians' discretion. Despite high sensitivity and positive predictive value of pathological physical examination findings, the number of patients with pathological physical examination findings were, also, small. These results must be confirmed by further studies including larger number of blunt MTT patients with pathological physical examination findings.

\section{References}

1. Battistelle F, Benfield JR. Blunt and penetrating injuries of the chest wall, pleura and lungs. In: Shields TW, ed. General Thoracic Surgery 4th ed. USA. Williams and Wilkons Company; 2002:815-31.

2. Shweiki E, Klena J, Wood GC, Indeck M. Assessing the True Risk of Abdominal Solid Organ Injury in Hospitalized Rib Fracture Patients. J Trauma 2001;50(4):684-8.

3. Sırmali M, Türüt $H$, Topçu $S$, Gülhan E, Yazıcı U, Kaya $S$, et al. A comprehensive analysis of traumatic rib fractures: morbidity, mortality and management. Eur J Cardiothorac Surg 2003;24(1):133-8.

4. Ziegler DW, Agarwal NN. The morbidity and mortality of rib fractures. J Trauma 1994;37(6):975-9.

5. National Centre for Health Statistics. National hospital ambulatory medical care survey. Hyattsville, MD. Centres for Disease Control and Prevention Availablefrom: www. cdc. gov/ nchs/ahcd. htm; 2009 [accessed 0505 14].

6. Kerr-Valentic MA, Arthur M, Mullins RJ, Pearson TE, Mayberry JC. Rib fracture pain and disability: can we do better? J Trauma 2003;54(6):1058-63.

7. Misthos P, Kakaris S, Sepsas E, Athanassiadi K, Skottis I. A prospective analysis of occult pneumothorax, delayed pneumothorax and delayed hemothorax after minor blunt thoracic trauma. Eur J Cardiothorac Surg 2004;25(5):859-64.

8. Shorr RM, Crittenden M, Indeck M, Hartunian SL, Rodriguez A. Blunt thoracic trauma. Analysis of 515 patients. Ann Surg 1987;206:200-5.
9. Baker SP, O’Neill B, Haddon W Jr, Long WB. The injury severity score: a method for describing patients with multiple injuries and evaluating emergency care. J Trauma 1974;14:187-96.

10. Demirhana R, Onana B, Oz K, Halezeroğlu S. Comprehensive analysis of 4205 patients with chest trauma: a 10-year experience. Interactive Cardiovascular and Thorac Surg 2009;9:450-3.

11. Karadayi S, Nadir A, Sahin E, Celik B, Arslan S, Kaptanoglu M. An analysis of 214 cases of rib fractures. Clinics 2011;66(3):449-51.

12. Gabram SG, Schwartz RJ, Jacobs LM, Lawrence D, Murphy MA, Morrow JS, et al. Clinical management of blunt trauma patients with unilateral rib fractures: a randomized trial. World J Surg 1995;19(3):388-93.

13. Lien YC, Chen $\mathrm{CH}$, Lin HC. Risk Factors for 24-Hour Mortality After Traumatic Rib Fractures Owing to Motor Vehicle Accidents: A Nationwide Population-Based Study. Ann ThoracSurg 2009;88(4):1124-30.

14. Whitson BA, Mcgonigal MD, Andersonm CP, Dries DJ. Increasing Numbers of Rib Fractures Do Not Worsen Outcome: An Analysis of the National Trauma Data Bank. Am Surg 2013;79:140-50.

15. Plourde M, Emond M, Lavoie A, Guimont C, Le Sage N, Chauny JM, et al. Cohort study on the prevalence and risk factors for delayed pulmonary complications in adults following minor blunt thoracic trauma. CJEM 2014;16(2):136-43.

16. Fuhrman CR, Britton CA, Bender T, Sumkin JH, Brown ML, Holbert JM, et al. Observer performance studies: detection of single versus multiple abnormalitiesof the chest. AJR Am J Roentgenol 2002;179(6):1551-3.

17. Rainer TH, Griffith JF, Lam E, Lam PK, Metreweli C. Comparison of thoracic ultrasound, clinical acumen, and radiography in patients with minor chest injury. J Trauma 2004;56(6):1211-3.

18. Shields JF, Emond M, Guimont C, Pigeon D. Acute minor thoracic injuries: Evaluation of practice and follow-up in the emergency department. Can Fam Physician 2010;56:117-24.

19. Palas J, Matos AP, Mascarenhas V, Herédia V, Ramalho M. Multidetector computer tomography: evaluation of blunt chest trauma in adults. Radiol Res Pract 2014;864369.

20. Sharma OP, Hagler S, Oswanski MF. Prevalence of delayed hemothorax in blunt thoracic trauma. Am Surg 2005;71(6):481-6. 